\author{
ORIGINAL ARTICLE
}

\title{
Toxic reagents and expensive equipment: are they really necessary for the extraction of good quality fungal DNA?
}

\author{
P. Rodrigues ${ }^{1}$, A. Venâncio ${ }^{2}$ (D) and N. Lima² \\ 1 Centro de Investigação de Montanha (CIMO), ESA, Instituto Politécnico de Bragança, Campus de Santa Apolónia, Bragança, Portugal \\ 2 Centre for Biological Engineering, Universidade do Minho, Braga, Portugal
}

Significance and Impact of the Study: There are numerous methods for DNA extraction from fungi. Some rely on expensive commercial kits and/or equipments, unavailable for many laboratories, or make use of toxic chemicals such as chloroform, phenol and mercaptoethanol. This study clearly demonstrates that it is possible to obtain high yields of pure DNA from pigmented conidia without the use of strong and expensive cell disrupting procedures and of toxic reagents. The method herein described is simultaneously inexpensive and adequate to DNA extraction from several different types of fungi.

Keywords

Aspergillus, DNA extraction, fungi, genomics, PCR.

\section{Correspondence}

Paula Rodrigues, Centro de Investigação de Montanha (CIMO), ESA, Instituto Politécnico de Bragança, Campus de Santa Apolónia, 5300-253 Bragança, Portugal.

E-mail: prodrigues@ipb.pt

2017/1008: received 24 May 2017, revised 14 September 2017 and accepted 15 September 2017

doi:10.1111/lam.12822

\begin{abstract}
The aim of this work was to evaluate a fungal DNA extraction procedure with the lowest inputs in terms of time as well as of expensive and toxic chemicals, but able to consistently produce genomic DNA of good quality for PCR purposes. Two types of fungal biological material were tested - mycelium and conidia - combined with two protocols for DNA extraction using Sodium Dodecyl Sulphate (SDS) and Cetyl Trimethyl Ammonium Bromide as extraction buffers and glass beads for mechanical disruption of cell walls. Our results showed that conidia and SDS buffer was the combination that lead to the best DNA quality and yield, with the lowest variation between samples. This study clearly demonstrates that it is possible to obtain high yield and pure DNA from pigmented conidia without the use of strong cell disrupting procedures and of toxic reagents.
\end{abstract}

\section{Introduction}

Fungi are highly important organisms in nature, due to their ecological, economical, industrial and pathogenic roles. Research on systematics, phylogenetics, as well as on ecophysiological, molecular and toxicological aspects are all dependent on nucleic acid analysis.

Some of the most significant nucleic acid analysis protocols, independently of the research goal or fungal source, usually involve DNA extraction and downstream PCR-based methods. Numerous DNA extraction methods have been developed and successfully used in fungal cells. Some rely on expensive commercial kits and/or equipments (Haugland et al. 2002; Dean et al. 2004; Karakousis et al. 2006; Hohnadel et al. 2014), unavailable for many laboratories. Others are long and tedious, and make use of toxic chemicals such as chloroform, phenol and mercaptoethanol (Gontia-Mishra et al. 2014), or require protein digestion steps with lyticase or proteinase $\mathrm{K}$ (Chen et al. 2002; Karakousis et al. 2006).

Whatever the case, good quality fungal DNA is usually hard to obtain and protocols are not always consistent in the obtained results. Problems with extraction of nucleic acids from filamentous fungi are basically caused by the compact cell wall structure consisting of chitin, (1-3)- $\beta$ D-glucan, $(1,6)$ - $\beta$-glucans, lipids, peptides and sometimes melanin, which are resistant to enzymatic digestion and chemical breakdown (Karakousis et al. 2006), which easily contaminate DNA extracts. An efficient mechanical cell disruption process is thus necessary. Some DNA extraction protocols have been described that include very simple disruption steps, like heating (Liu et al. 2011; Turan et al. 2015), sonication (Karakousis et al. 2006; Hohnadel et al. 2014) or bead milling using grinding homogenizers 
(Nijs et al. 1996; Haugland et al. 2002; Dean et al. 2004; Karakousis et al. 2006), but these have shown inconsistent levels of success. Grinding with mortar and pestle in liquid nitrogen $\left(\mathrm{N}_{2}\right)$ is usually reported as the most efficient method for fungal cell disruption (Nijs et al. 1996; Haugland et al. 2002; Karakousis et al. 2006). Unfortunately, this method is not user-friendly, is highly prone to sample loss and contamination because of sample droplets, and $\mathrm{N}_{2}$ is not always available to laboratories.

After cell disruption, processes of fungal DNA purification are frequently adapted from plant DNA extraction protocols. Purification steps most often include betamercaptoethanol and polyvinylpyrrolidone (PVP) to help eliminate polyphenols and other phenolic compounds, proteins, pigments and other contaminants, as well as phenol/chloroform mixture (Chen et al. 2002; Karakousis et al. 2006; Gontia-Mishra et al. 2014), which generally improve DNA purity, but are toxic and not suitable for routine handling.

Simple and safe handling, low equipment dependence and use of easily available reagents are highly desired features for almost all research laboratories, mostly for lowincome and less-equipped ones. Also, the development of more environmental- and user-friendly methods making use of less toxic reagents is strongly favoured.

The work presented here aimed to implement a protocol that would be fast, non-toxic, economic and nondependable on irregular supplies or expensive equipment, but able to consistently produce fungal genomic DNA of good quality for PCR purposes. For this, two types of fungal material were tested - mycelium and conidia combined with two protocols for DNA extraction: Sodium Dodecyl Sulphate (SDS) protocol and Cetyl Trimethyl Ammonium Bromide (CTAB) protocol, using glass beads for mechanical disruption of cell walls. In total, four protocols were tested: Mycelium/SDS, Mycelium/CTAB, Conidia/SDS and Conidia/CTAB.

\section{Results and discussion}

The evaluation of DNA purity was done by determining the spectrophotometric ratios $A_{260} / A_{280}$ and $A_{260} / A_{230}$. Results obtained for the tested methods are shown in Fig. 1. For simplicity of analysis, a horizontal reference line at ratio 2.0 was included in both Fig. 1a,b. Ratios falling between 1.8 and 2.1 were considered to represent DNA of high purity. For the $A_{260} / A_{280}$ ratio, deviating values denote high protein contamination, and DNA should be further treated with proteinase $\mathrm{K}$ for protein digestion. The ratio $A_{260} / A_{230}$ is affected by presence of salt and amino acid contaminants. If outside the range, DNA should be further washed with ethanol. For both ratios, there was no significant difference observed between methods $(P>0.05)$. Protein contamination was low on average, as shown by $\mathrm{A}_{260} / \mathrm{A}_{280}$ levels close to $2 \cdot 0$, but methods using mycelium as the starting material resulted in more deviation between samples, with the Conidia/SDS method showing the best results. On the other hand, the observed $\mathrm{A}_{260} / \mathrm{A}_{230}$ ratio generally resulted in higher variability between samples and ratio values higher than the reference value, except for the Conidia/ SDS method. Thus, the Conidia/SDS method was considered as the optimal method, resulting in highly pure DNA, with less variability between samples.

Figure 2 presents the results obtained for nucleic acid concentration. Statistical analysis determined that no significant difference existed between extraction methods $(P>0.05)$. Similarly to the results observed for purity, a high difference in concentration was observed between samples of the same method, except for the Conidia/SDS protocol. DNA yield for this method was on average $250 \mu \mathrm{g} \mathrm{ml}^{-1}$ (1 $\mu \mathrm{g}$ of DNA per mg of conidia fresh weight; or an absolute DNA yield of $25 \mu \mathrm{g}$ in a final elution volume of $100 \mu \mathrm{l}$ ). This is comparable with other methods using stronger mechanical or enzymatic lysis
Figure 1 Spectrophotometric results of purity for genomic DNA obtained by the four extraction protocols $(n=5)$ : (a) $\mathrm{A}_{260} / \mathrm{A}_{280}$; (b) $A_{260} / A_{230}$. Horizontal bars indicate reference values. $(\square) A_{260} / A_{280}$ and $(\square) A_{260}$ $\mathrm{A}_{230}$.

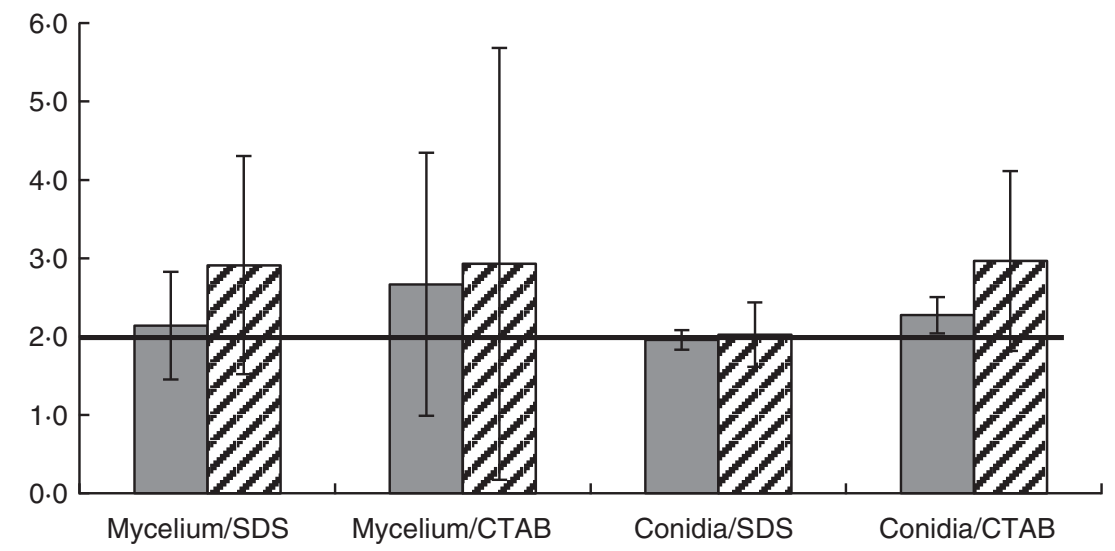




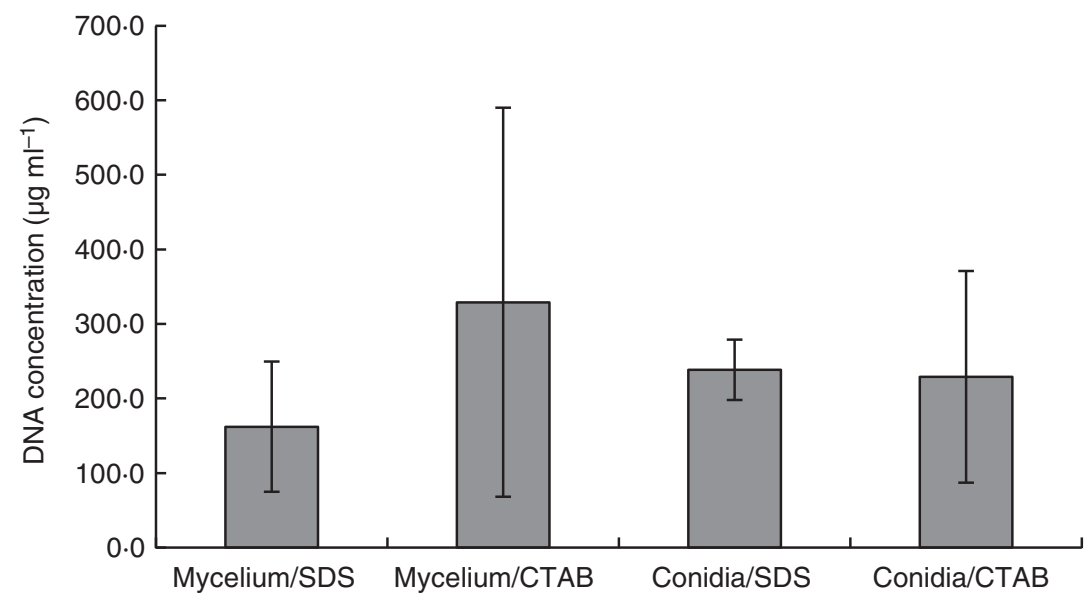

Figure 2 DNA concentration (in $\mu \mathrm{g} \mathrm{ml}^{-1}$ ) obtained by reading absorbance at 260 wave length $(n=5)$. Vertical bars indicate maximum and minimum values. procedures (Nijs et al. 1996; Amer et al. 2011), although lower than that obtained by liquid nitrogen maceration (Nijs et al. 1996).

The aim of this work was to evaluate a good DNA extraction procedure with the lowest input in terms of time as well as expensive and toxic chemicals. For that reason, RNA treatment was intentionally excluded from the protocols. One downside of this is that RNA will necessarily contaminate DNA samples. This contamination is usually not a problem in terms of downstream PCR amplification steps but it is important to emphasize that spectrophotometric quantification by $A_{260}$ will include both DNA and RNA, without being able to differentiate between these two nucleic acids in a given sample. Consequently, DNA concentration as determined by spectrophotometry should be analysed carefully when the extract is not subject to RNA enzymatic digestion. The analysis of genomic DNA by electrophoresis in agarose gels is thus of major importance to obviate the RNA contamination issue. Also, this is the only way to determine DNA integrity. Gel electrophoresis of DNA samples obtained in this study is presented in Figure 3. As can be seen, methods where mycelium was used as the starting material (Fig. 3a,b) denote high levels of RNA (blurs at the bottom of the gel), and undetectable genomic DNA. Whenever conidia were used for DNA extraction, the SDS extraction protocol resulted in highly integral and pure DNA, observed by the sharp lines on the top of the gel (Fig. 3c). Method Conidia/CTAB was also able to produce DNA at high concentrations, but apparently with lower integrity and quality (Fig. 3d). Similar studies have shown that the use of mechanical homogenizers for cell disruption resulted in lower DNA recovery or severe DNA shearing (Nijs et al. 1996).

Considering the results of both spectrophotometric and electrophoretic analyses, mycelium was considered unsuitable for mechanical disruption by vortexing with glass beads, independently of the extraction protocol. On the other hand, conidia resulted in high amounts of good quality DNA. Both types of material have disadvantages as source material for DNA extraction: conidia are heavily pigmented and have hard cell walls, which can result in low DNA purity and concentration; young mycelium cell walls are not as hard, but they can form a mesh around glass beads, making cell disruption difficult to accomplish. Given the observed results, methods using mycelium as biological material were excluded from further analysis.

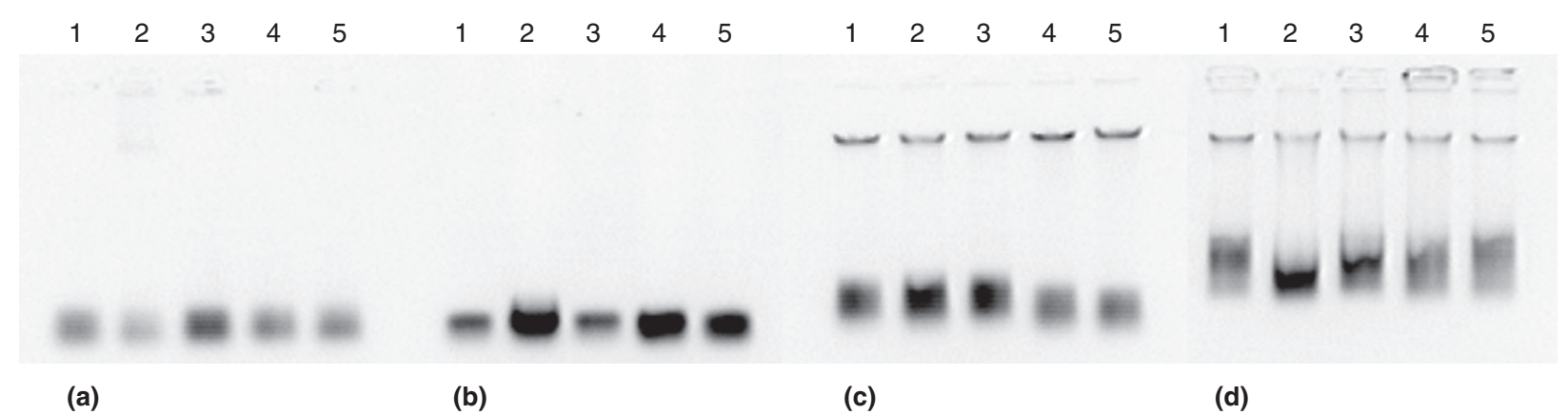

Figure 3 Electrophoresis results for genomic DNAs obtained by the four protocols tested. (a) Mycelium/SDS; (b: Mycelium/CTAB; (c) Conidia/SDS; (d) Conidia/CTAB. Lanes 1 to 5 in each gel correspond to the five isolates tested. 


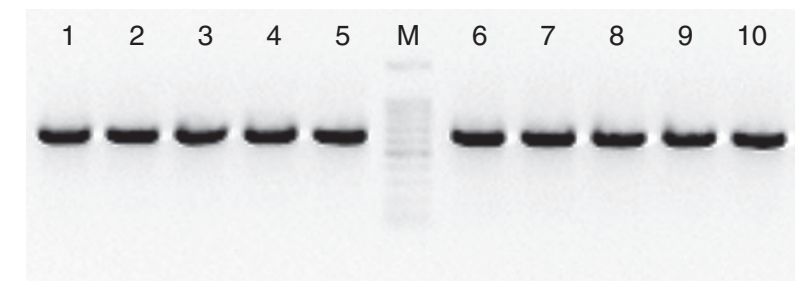

Figure 4 Electrophoretic results of the ITS region amplification. Lanes: 1 to 5 - Samples obtained by the protocol Conidia/SDS; 6 to $10-$ Samples obtained by the protocol Conidia/CTAB; $M-100$ bp DNA ladder.

To confirm the ability of extracted DNA to be used in downstream steps involving PCR amplification, DNA extracts were used as template for the amplification of the universal ITS region of the rRNA gene. For this test, only DNA extracts obtained by Conidia/SDS and Conidia/ CTAB methods were used. Figure 4 illustrates the results of this amplification. Genomic DNAs obtained by both methods were found to be equally suitable for PCR analysis, all resulting in strong and well defined amplicons. However, the CTAB method is more time consuming than the SDS method, and involves the use of toxic chemicals (mercaptoethanol, chloroform and phenol).

Results herein described refer to five strains of Aspergillus flavus and Aspergillus parasiticus, but the Conidia/SDS method has since been successfully applied to numerous other filamentous fungi, e.g. Aspergillus tamarii, Aspergillus nomius, Aspergillus niger complex, Aspergillus westerdijkiae, Aspergillus fumigatus, Penicillium nordicum, Penicillium brevicompactum, Penicillium chrysogenum, Penicillium commune, Talaromyces rugulosus, Ascosphaera apis (data not shown), for both multi-copy rRNA genes (ITS region) and single-copy genes (calmodulin and b-tubulin, amplified with the primer pairs $\mathrm{Cl} 1-\mathrm{Cl} 2 \mathrm{~A}$ and $\mathrm{Bt} 2 \mathrm{a}-\mathrm{Bt} 2 \mathrm{~b}$ respectively) (Rodrigues et al. 2011). Several yeasts, e.g. Rhodotorula mucilaginosa, Candida zeylanoides and Candida krusei have also been successfully amplified and sequenced (using primer pairs NL1-NL4) from DNA obtained from this method (Meftah et al. 2018). DNA extracted by this method has proved adequate for PCR even after 5 years, when stored at $-20^{\circ} \mathrm{C}$ in ultra-pure water.

Overall, the SDS extraction method takes approx. $2 \mathrm{~h}$ to extract a batch of 12 samples, including some short incubation periods that allow for the operator to initiate the following set of samples. This allows for one operator to easily process three batches a day. Other methods are reported to be faster and able to process higher numbers of samples per day, but they have been optimized for a specific type of fungus (Turan et al. 2015), and are not always successful when applied to others.
In the method herein described, mechanical disruption of conidia cell walls is easily achieved by vortexing with glass beads inside a closed tube, which substitutes the need for grinding with a pestle thus reducing the risk of cross contamination as well as labour. When working with pathogenic or toxigenic fungal species, this aspect is also of significance, as it reduces the chance of generating hazardous droplets.

This study demonstrates the high quality of the DNA extraction method using conidia as biological material and SDS as extraction buffer. It is shown that with this method it is possible to obtain high yield and pure DNA from pigmented conidia without the use of strong cell disrupting procedures like $\mathrm{N}_{2}$ maceration and of toxic reagents like phenol or mercaptoethanol. The SDS method is technically easy, inexpensive, it does not require liquid nitrogen or toxic chemicals, thus being safe for the operators and the environment, and is not dependent of specific and expensive equipment. It can be easily implemented in laboratories with limited resources as a routine method for DNA extraction from virtually all types of fungi.

\section{Materials and methods}

\section{Preparation of fungal material}

DNA extraction was tested using two types of biological material: mycelium and conidia. On this matter, the aim was not to obtain exclusively conidia and mycelium, but rather obtain predominantly one or the other. Biological materials tested for DNA extraction were prepared as follows:

Mycelium $10 \mathrm{ml}$ of Malt Extract Broth (MEB: Malt Extract $20 \mathrm{~g} \mathrm{l}^{-1}$, Glucose $20 \mathrm{~g} \mathrm{l}^{-1}$, Peptone $1 \mathrm{~g} \mathrm{l}^{-1}$ ) (in a $50 \mathrm{ml}$ Falcon tube) were inoculated with a loop full of spores and incubated for $72 \mathrm{~h}$ at $25^{\circ} \mathrm{C}$, in the dark, with slight agitation. Mycelium was collected by centrifugation at $14000 \mathrm{~g}$ for $10 \mathrm{~min}$, washed twice with $10 \mathrm{ml}$ of $0 \cdot 85 \%$ $\mathrm{NaCl}$ and centrifuged at $14000 \mathrm{~g}$ for $10 \mathrm{~min}$. Mycelium was collected and used for DNA extraction.

Conidia A $6 \mathrm{~cm}$ Petri dish containing $10 \mathrm{ml}$ of Malt Extract Agar (MEA: Malt Extract $20 \mathrm{~g} \mathrm{l}^{-1}$, Glucose $20 \mathrm{~g} \mathrm{l}^{-1}$, Peptone $1 \mathrm{~g} \mathrm{l}^{-1}$, Agar $2 \mathrm{~g} \mathrm{l}^{-1}$ ) was inoculated with a loop full of spores and incubated for $7 \mathrm{~d}$ at $25^{\circ} \mathrm{C}$ in the dark. Conidia were collected with the aid of a loop previously wet in $0 \cdot 2 \%$ agar with $0.05 \%$ Tween 80 , to help the adherence of spores, and used directly for DNA extraction.

All tests were run on five isolates of Aspergillus section Flavi isolated from Portuguese almonds: two strains of A. flavus and three strains of $A$. parasiticus. Even though the amount of used biomass was not quantitatively 
determined (to maintain the simplicity of the method), approximately the same amount of conidia or mycelium (equivalent to a loop full) was taken from each fungus.

\section{Methods of DNA extraction}

SDS method

The biological material (approx. $25 \mathrm{mg}$ of fresh mycelium or conidia, as prepared previously) was transferred to a $15 \mathrm{ml}$ tube containing $1.5 \mathrm{ml}$ of Lysis Buffer SDS (200 mmol $\mathrm{l}^{-1}$ Tris-HCl pH 8.5; 250 mmol $\mathrm{l}^{-1} \mathrm{NaCl}$; $25 \mathrm{mmol} \mathrm{l}^{-1}$ EDTA; 0.5\% (w/v) SDS) and approx. $1 \mathrm{~g}$ of sterile 0.4 - to $0.6-\mathrm{mm}$ diameter glass beads (Sigma, St. Louis, MO), previously acid-washed. The mixture was vortexed for $5 \mathrm{~min}$ at maximum speed. Polysaccharides and proteins were precipitated by adding $750 \mu \mathrm{l}$ of cold $3 \mathrm{~mol} \mathrm{l}^{-1}$ sodium acetate, $\mathrm{pH} 5 \cdot 5$. This was gently mixed by inversion, placed at $-20^{\circ} \mathrm{C}$ for $10 \mathrm{~min}$ and centrifuged twice at $14000 \mathrm{~g}$ for $10 \mathrm{~min}\left(4^{\circ} \mathrm{C}\right)$. Clean supernatant was then transferred to a new tube and precipitated with 1 volume of cold isopropanol $\left(-20^{\circ} \mathrm{C}\right)$. This solution was gently mixed by inversion for a few min, incubated at $-20^{\circ} \mathrm{C}$ for $1 \mathrm{~h}$ (or at $-80^{\circ} \mathrm{C}$ for $10 \mathrm{~min}$ ) and centrifuged at $14000 \mathrm{~g}$ for $10 \mathrm{~min}\left(4^{\circ} \mathrm{C}\right)$. DNA pellet was washed twice with $1.0 \mathrm{ml}$ of cold $70 \%$ ethanol, centrifuged at $6000 \mathrm{~g}$ for $7 \mathrm{~min}\left(4^{\circ} \mathrm{C}\right)$ and air dried. DNA was dissolved in $100 \mu \mathrm{l}$ of ultra-pure water and stored at $-20^{\circ} \mathrm{C}$.

\section{CTAB method}

The biological material (approx. $25 \mathrm{mg}$ of fresh mycelium or conidia, as prepared previously) was transferred to a $15 \mathrm{ml}$ tube containing $1.5 \mathrm{ml}$ of Lysis Buffer CTAB $\left(100 \mathrm{mmol} \mathrm{l}^{-1}\right.$ Tris-HCl pH 8.0; $1.4 \mathrm{~mol} \mathrm{l}^{-1} \mathrm{NaCl}$; $20 \mathrm{mmol} \mathrm{l}^{-1}$ EDTA pH 8.0; 2\% CTAB (p/v); 0.4$\%$ polyvinylpyrrolidone (PVP) (p/v); $0.05 \% \beta$-mercaptoethanol $(\mathrm{v} / \mathrm{v}))$ and $1 \mathrm{~g}$ of $0 \cdot 4$ - to $0 \cdot 6$ - $\mathrm{mm}$-diameter glass beads (Sigma), previously washed with nitric acid, vortexed for $5 \mathrm{~min}$ at maximum speed and incubated at $65^{\circ} \mathrm{C}$ for $15 \mathrm{~min}$. Vortexing and incubation were repeated and $1.5 \mathrm{ml}$ of $24: 1$ chloroform:isoamyl alcohol were added. The mixture was thoroughly homogenized by agitation and centrifuged for $10 \mathrm{~min}$ at $14000 \mathrm{~g} \cdot 1 \cdot 2 \mathrm{ml}$ of the aqueous phase were transferred into a tube containing $0.7 \mathrm{ml}$ of isopropanol and $0.1 \mathrm{ml}$ of $7.5 \mathrm{~mol} \mathrm{l}^{-1}$ $\mathrm{NH}_{4} \mathrm{OAc}$. The mixture thoroughly homogenized by agitation and centrifuged for $10 \mathrm{~min}$ at $14000 \mathrm{~g}$. The supernatant was discarded and the pellet (DNA) was washed with $1.5 \mathrm{ml}$ of cold $70 \%$ ethanol $\left(-20^{\circ} \mathrm{C}\right)$, followed by a centrifugation for $10 \mathrm{~min}$ at $14000 \mathrm{~g}$. The supernatant was discarded and the pellet was air-dried until all the ethanol had evaporated. DNA was dissolved in $100 \mu \mathrm{l}$ of ultra-pure water and stored at $-20^{\circ} \mathrm{C}$.

\section{Evaluation of DNA quality and concentration}

Quality and concentration of genomic DNAs obtained from the different protocols were determined by horizontal gel electrophoresis and by spectrophotometry. Electrophoretic analysis was done on $1 \%$ agarose gel with Tris-Acetate-EDTA buffer (TAE: $40 \mathrm{mmol}^{-1}$ Tris- $\mathrm{HCl}$; $40 \mathrm{mmol} \mathrm{l}^{-1}$ acetic acid; $1.0 \mathrm{mmol} \mathrm{l}^{-1}$ EDTA, pH 8.0) stained with GelRed (VWR). Runs were made in TAE buffer, at constant voltage of $5 \mathrm{~V} \mathrm{~cm}^{-1}$ for approx. $1 \mathrm{~h}$. Five microlitres of genomic DNA and $1 \mu \mathrm{l}$ of Orange Blue Loading Buffer (Promega) were loaded on the gel. DNA was visualised under UV light and images were obtained by the image analysis system Eagle Eye II (Stratagene). For the spectrophotometric analysis, absorbance readings were made at $230 \mathrm{~nm}\left(\mathrm{~A}_{230}\right), 260 \mathrm{~nm}$ $\left(\mathrm{A}_{260}\right)$ and $280 \mathrm{~nm}\left(\mathrm{~A}_{280}\right)$ in quartz microcuvettes. DNA concentration was calculated as follows: (DNA) $\mu \mathrm{g} \mathrm{ml}^{-1}=\mathrm{A}_{260} \times$ Dilution Factor $\times 50$.

DNA purity relative to protein contamination and to salt and amino acid contamination was determined by the ratios $A_{260} / A_{280}$ and $A_{260} / A_{230}$, respectively.

\section{Evaluation of DNA quality for PCR amplification}

Genomic DNAs were further tested for purity and concentration by amplification of the multi-copy universal ITS1/5.8S/ITS2 region of the rRNA gene. The primers ITS1-F (5'-CTTGGTCATTTAGAGGAAGTAA- $\left.3^{\prime}\right)$ and ITS4 (5'-TCCTCCGCTTATTGATATGC-3') (White et al. 1990; Gardes and Bruns 1993), which amplify a 600 bp segment, were used for this purpose. PCRs were run in a BioRad Mycycler thermalcycler on $25 \mu \mathrm{l}$ reaction mixtures composed of: 1.25 U GoTaq Flexi DNA Polymerase (Promega, \#M8305), 1× GoTaq Flexi Green Buffer without $\mathrm{MgCl}_{2}, 1.5 \mathrm{mmol} \mathrm{l}^{-1} \mathrm{MgCl}_{2}, 0.2 \mathrm{mmol} \mathrm{l}^{-1}$ of each dNTP (dNTP Mix, Promega, \#U1511), 0.2 $\mu \mathrm{mol} \mathrm{l}^{-1}$ of each primer, and $50 \mathrm{ng}$ of genomic DNA. The PCR program was as follows: Initial denaturation for $3 \mathrm{~min}$ at $94^{\circ} \mathrm{C}, 35$ cycles of $94^{\circ} \mathrm{C}$ for $30 \mathrm{~s}, 55^{\circ} \mathrm{C}$ for $30 \mathrm{~s}$ and $72^{\circ} \mathrm{C}$ for $2 \mathrm{~min}$, and a final extension cycle at $72^{\circ} \mathrm{C}$ for $10 \mathrm{~min}$.

PCR products were separated on a $1.5 \%$ agarose/TAE gel, stained with GelRed and compared to the DNA size marker 100 bp DNA Ladder (Promega, \#G2101). Electrophoretic runs and image acquisition were as previously described.

\section{Statistical analysis}

For the comparison of means, samples were first tested for normal distribution by Shapiro-Wilk test (for $n<30$ ) and for homogeneity of variances by Levene's test. Since samples failed the two premises, samples were analysed 
pairwise by the non-parametric Kruskal-Wallis test for a significance level of 0.05.

\section{Acknowledgements}

This work was supported by the Foundation for Science and Technology (FCT, Portugal) and the European Social Fund through the grant SFRH/BD/28332/2006; by Fundação para a Ciência e a Tecnologia and the Polytechnic Institute of Bragança through the grant SFRH/PROTEC/49555/2009; and by the European Community's Seventh Framework Program (FP7,2007/2013), Research Infrastructures Action, Under Grant Agreement Fp7228310 (Embarc Project). The authors are also grateful to the Foundation for Science and Technology (FCT, Portugal) and FEDER under Programme PT2020 for financial support to CIMO (UID/AGR/00690/2013).

\section{Conflict of Interest}

No conflict of interest declared.

\section{References}

Amer, O.E., Mahmoud, M.A., El-Sawmawaty, A.-R.M.A. and Sayed, S.R.M. (2011) Non liquid nitrogen-based-method for isolation of DNA from filamentous fungi. Afr J Biotechnol 10, 14337-14341.

Chen, S.C., Halliday, C.L. and Meyer, W. (2002) A review of nucleic acid-based diagnostic tests for systemic mycoses with an emphasis on polymerase chain reaction-based assays. Med Mycol 40, 333-357.

Dean, T.R., Betancourt, D. and Menetrez, M.Y. (2004) A rapid DNA extraction method for PCR identification of fungal indoor air contaminants. J Microbiol Methods 56, 431-434.

Gardes, M. and Bruns, T.D. (1993) ITS primers with enhanced specificity for basidiomycetes - application to the identification of mycorrhizae and rusts. Mol Ecol 2, 113-118.

Gontia-Mishra, I., Tripathi, N. and Tiwari, S. (2014) A simple and rapid DNA extraction protocol for filamentous fungi efficient for molecular studies. Ind J Biotechnol 13, 536539.

Haugland, R.A., Brinkman, N. and Vesper, S.J. (2002) Evaluation of rapid DNA extraction methods for the quantitative detection of fungi using real-time PCR analysis. J Microbiol Methods 50, 319-323.

Hohnadel, M., Felden, L., Fijuljanin, D., Jouette, S. and Chollet, R. (2014) A new ultrasonic high-throughput instrument for rapid DNA release from microorganisms. J Microbiol Methods 99, 71-80.

Karakousis, A.D., Ellis, L.T., Alexiou, H. and Wormald, P.J. (2006) An assessment of the efficiency of fungal DNA extraction methods for maximizing the detection of medically important fungi using PCR. J Microbiol Methods 65, 38-48.

Liu, K.-H., Yeh, Y.-L. and Shen, W.-C. (2011) Fast preparation of fungal DNA for PCR screening. J Microbiol Methods 85, 170-172.

Meftah, S., Abid, S., Dias, T. and Rodrigues, P. (2018) Effect of dry-sausage starter culture and endogenous yeasts on Aspergillus westerdijkiae and Penicillium nordicum growth and OTA production. LWT - Food Sci Technol 87, 250258.

Nijs, M., Nabben, L. and Wernars, K. (1996) Isolation of Fusarium DNA for molecular analysis with and without mechanical cell disruption. J Microbiol Methods 27, $13-17$.

Rodrigues, P., Santos, C., Venâncio, A. and Lima, N. (2011) Species identification of Aspergillus section Flavi isolates from Portuguese almonds using phenotypic, including MALDI-TOF ICMS, and molecular approaches. J Appl Microbiol 111, 877-892.

Turan, C., Nanni, I.M., Brunelli, A. and Collina, M. (2015) New rapid DNA extraction method with Chelex from Venturia inaequalis spores. J Microbiol Methods 115, 139-143.

White, T.J., Burns, T., Lee, S. and Taylor, J.W. (1990) Amplification and direct sequencing of fungal ribosomal RNA genes for phylogenetics. In PCR Protocol: A Guide to Methods and Applications, ed. Innis, M.A., Gelfald, D.H., Sninsky, J.J. and White, T.J. pp. 315-322. Cambridge, MA: Academic Press. 